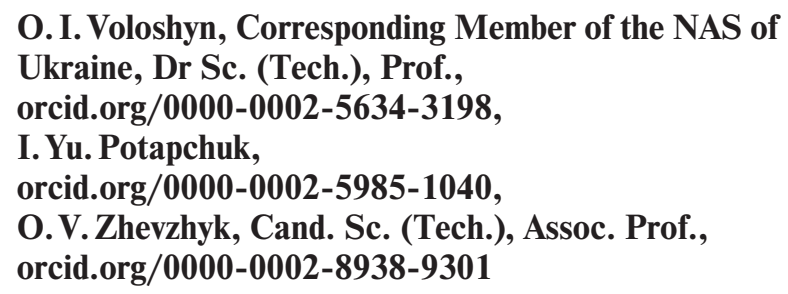

M. S. Polyakov Institute of Geotechnical Mechanics of the NAS of Ukraine, Dnipro, Ukraine, e-mail: OIVoloshyn1951@nas. gov.ua; IYPotapchuk@nas.gov.ua; OVZhevzhyk@nas.gov.ua

\title{
INFLUENCE OF THE HEAT-TRANSFER STREAM PRESSURE ON THE SURFACE OF THE ROCK IN A PROCESS OF THE THERMAL REAMING OF THE BOREHOLE
}

\begin{abstract}
Purpose. Experimental research on the high-speed interaction of the heat transfer medium jet with the surface of the borehole in the process of fragile rock destruction with the purpose of determination of the heat transfer medium velocity along the borehole surface and the heat transfer coefficient from the heat transfer medium to the rock sur-
\end{abstract} face.

Methodology. Methods of comparative analysis, mathematic and physical simulation modelling as well as experimental research are used.

Findings. The methodology of experimental research on high-speed interaction of the heat transfer medium jet with the surface of borehole as the lateral surface of the cross duct imitated the rock surface in a borehole is developed. Experimental research that consisted of pressure measurement on the lateral surface of the cross duct at the air jet impingement on the lateral surface is conducted. Experimental research treatment is executed as dependence of absolute pressure at the lateral surface of the cross duct, i.e. absolute pressure on the rock surface, from relative pressure of air before a nozzle and relative diameter of the cross duct. Dependences between the values of pressure before a nozzle and values of pressure on the rock surface, values of relative diameter of the cross duct, nozzle outlet diameter, inner diameter of the cross duct and values of air pressure along the lateral surface of the duct are determined.

Originality. The work presents physical imitational modelling of high-speed interaction of the heat transfer medium jet with the surface of the borehole in a certain range of geometrical parameters of the cross duct and the nozzle, that is accepted in accordance with geometrical similarity to the technological and processing parameters of plasmatron and borehole diameter before the beginning of thermal reaming process.

Practical value. Expediency of high-speed plasma jets application as a thermal tool in the processes of fragile rock destruction and, in particular, in the processes of thermal reaming of the boreholes is substantiated.

Keywords: rock, borehole, fragile destruction, thermal reaming, plasma

Introduction. Taking into account the productivity and expenditures for realization of various methods for the borehole drilling and reaming, thermal methods for rock destruction are of the most interest.

Application urgency of thermal methods for destruction is conditioned by the wide spectrum of facilities for realization of the operation of rock heating.

In the cases of application of thermal methods for rock destruction the destruction products move away from the rock mass under the influence of the shear and tensile thermal stresses.

It is known that the strength limit for shearing and stretching is approximately 7-10 times less than the strength limit for the compression. Therefore, a thermal method for rock destruction is the most energy saving method for destruction.

With increasing temperature in a heating area along with the decreasing strength and aggregate hardness, rock fragility decreases, which allows using the thermal methods for rock destruction effectively not only in the processes of the borehole drilling, but also in the processes of the boreholes reaming [1].

(C) Voloshyn O. I., Potapchuk I. Yu., Zhevzhyk O. V., 2018
Most effective amid the processes of the borehole reaming are the thermal ones, in particular, those with application of the gas jet heating of rock with usage of arc electric discharge, because efficiency of these processes hardly depends on physical and mechanical properties of rock.

Plasma burners have some advantages [2, 3]:

- widened adjustment range of thermal parameters and concentration of the jet power;

- diminished amount of hazardous gases emission;

- simplified system of the burners automation.

Due to high velocity of the torch movement in a borehole an average velocity change of its temperature is provided for the range of .

Such thermal influence on the rock surface considerably increases efficiency of its thermal destruction.

Analysis of the recent research and publications. The analysis of scientific sources testifies that for the known devices with an arc electric discharge for rock destruction the ranges of operating performance of thermal tools, effective modes of heating, mechanical loading and fragile rock destruction were determined, mostly, in an experimental manner $[4,5]$. 
Prevailing majority of the known experimental investigations concerns the determination of time and temperature values of rock destruction [6].

Few publications are devoted to the problem of the experimental investigation of gas dynamics and plasma dynamics of the jets that are used as a heat transfer medium in the thermal methods of rock destruction.

The reference [7] presents average values of the heat transfer coefficient obtained by means of experimental investigation from the heat transfer medium to the rock surface, however insufficient attention is paid to the gas dynamics and interaction of the heat transfer medium jet with the borehole surface.

The reference [8] contains information about velocity of the heat transfer medium at the nozzle outlet and its value gains up to $120 \mathrm{~m} / \mathrm{s}$, which could be compared with velocity of plasma flow at the nozzle outlet of plasmatron; however, as a heat transfer medium an incompressible liquid is used. It makes impossible to use the results of the experimental investigation for determination of the heat transfer coefficient from plasma jet to the rock surface.

In the reference [9] for fragile rock destruction the high-speed (Mach number within the range of 2-5) and high temperature $\left(300-1100{ }^{\circ} \mathrm{C}\right)$ jets of the heat transfer medium were used.

However, the outflow of the heat transfer medium from a nozzle took place in the pulsatile mode, and efficiency of rock destruction depended on gauge pressure of the jet on the surface of the borehole, that was in the range of 5-20 $\mathrm{MPa}$.

There is a method for kerf cutting by means of plasma burner with the following thermophysical descriptions of the torch: effective temperature $-4000-$ $7000{ }^{\circ} \mathrm{C}$; maximal specific heat flux $-1.2 \cdot 10^{7} \mathrm{~W} / \mathrm{m}^{2}$; heat transfer coefficient - up to $14 \mathrm{MW} /\left(\mathrm{m}^{2} \cdot \mathrm{K}\right)$.

The effect of the plasma burner application in the process of the thermal drilling was the formation of cracks up to $0.1 \mathrm{~mm}$ that spread to considerable distance (1.2 $\mathrm{cm}$ and further) from the drilling channel.

Investigations of plasmatron having a power of 20$60 \mathrm{~kW}$ are known. Air consumption is $0.002-0.005 \mathrm{~kg} / \mathrm{s}$, electric current is 50-300 A. Thermophysical properties of plasmatron varied in the following ranges: heat transfer coefficient was within the range of 1.1611.6 MW/ $\left(\mathrm{m}^{2} \cdot \mathrm{K}\right)$, specific heat flux - within the range of $1.16-58 \mathrm{MW} / \mathrm{m}^{2}$.

Experimental investigation proved that application of air-water mixture as plasma generating gas increases plasmatron efficiency by $5-10 \%$ in efficiency comparison to plasmatrons with air stabilization of arc.

In addition, thermophysical parameters of the jet increase, since water supply to air causes its heating and dissociation.

During gas cooling in vicinity of a heating surface, recombination of dissociation components along with emission of thermal energy is observed.

Augmentation of water content increases enthalpy of the plasma jet.

Thus, application of water steam as plasma generating gas increases rock heating efficiency.
The jet inclination angle substantially influences thermophysical properties of the jet.

Increase in the jet inclination angle to the surface that is heated results in reduction of specific heat flux.

The jet inclination over the surface that is heated at $20-25^{\circ}$ does not diminish substantially heat flux to the surface.

The consequence of further increase in the inclination angle is a considerable reduction of heat flux.

Application of plasmatrons having a power about 25-30 kW for the borehole surface heating is known.

Distance from the nozzle exit to the borehole surface is $20 \mathrm{~mm}$, heat flux of the plasma jet is within the range of $5.82-11.64 \mathrm{MW} / \mathrm{m}^{2}$, the temperature of the jet is $4000 \mathrm{~K}$.

There is experimental investigation of the borehole reaming process of diameter up to $60 \mathrm{~mm}$ that was executed by means of plasmatron, whose operating parameters are shown in Table 1.

Mass-averaged temperature of the plasma jet was within the range of $3000-4000 \mathrm{~K}$.

At the air pressure of $0.35 \mathrm{MPa}$ plasma jet outflow from a nozzle occurs in the supersonic mode.

Specific heat flux on the rock surface was in the range of $(1.4-2.6) \cdot 10^{4} \mathrm{~kW} / \mathrm{m}^{2}$.

Velocity of device in a borehole was within the range of $3-8 \mathrm{~m} / \mathrm{hr}$.

With the aim of reducing the concentration of nitrogen oxides in gases released from plasma jet and increasing efficiency of energy transmission to rock, it is suggested to apply an open electric arc.

It will allow intensifying a heat exchange by radiation, as a temperature on the arc axis will reach 5000-10 $000 \mathrm{~K}$.

In the spectrum of arc radiation approximately $50 \%$ constitutes infrared radiation.

In the process of experimental investigation electric current of arc changed within the range of 90-150 A, air consumption was within the range of $1-3 \mathrm{~m}^{3} / \mathrm{hr}$, specific heat flux was $1 \mathrm{MW} / \mathrm{m}^{2}$.

Experimental investigation proved that at identical power and identical heating conditions (plasmatron power and open electric arc is $21 \mathrm{~kW}$, distance to the rock surface is $30 \mathrm{~mm}$ ) the amount of heat acquired by rock increases by $70-80 \%$ compared to the rock heating by open arc.

A method of the application of combustion chamber that provides increasing of thermal efficiency of plasma jet and reduction of nitrogen oxides content in a jet is known.

The operating parameters of plasmatron for this purpose are shown in Table 2.

\section{Table 1}

Operating parameters of the plasmatron

\begin{tabular}{|l|c|}
\hline \multicolumn{1}{|c|}{ Parameter } & Value \\
\hline Power, kW & $30-65$ \\
\hline $\begin{array}{l}\text { Diameter of the critical nozzle } \\
\text { cross-section, mm }\end{array}$ & $6-8$ \\
\hline Air consumption, kg/s & $0.005-0.010$ \\
\hline
\end{tabular}


Table 2

Table 5

Operating parameters of the plasmatron

\begin{tabular}{|l|c|}
\hline \multicolumn{1}{|c|}{ Parameter } & Value \\
\hline Power, kW & $1200-1600$ \\
\hline Discharge power, kW & $300-600$ \\
\hline Air consumption, kg/s & $0.3-0.4$ \\
\hline Mass-averaged jet temperature, K & $2500-2900$ \\
\hline $\begin{array}{l}\text { Mass-averaged velocity of the jet } \\
\text { outflow, m/s }\end{array}$ & $1000-1500$ \\
\hline Thermal efficiency & $0.7-0.8$ \\
\hline
\end{tabular}

The feature of another plasma generator is an air cooling of heat-stressed units.

Such technological decision allowed increasing a discharge power by $20 \%$.

The operating parameters of this plasmatron purpose are shown in Table 3.

The results of experimental investigation of plasma method of thermal borehole reaming from an initial diameter 100 to $500 \mathrm{~mm}$ on a depth up to $70 \mathrm{~m}$ is known.

The operating parameters of plasmatron are shown in the Table 4.

Reaming velocity of the borehole reaming by the example of magnetite quartzites is shown in Table 5.

Results of the known experimental investigation of the boreholes thermal reaming by means of plasmatron are presented in Table 6.

In common, all known technical decisions that concern application of thermal tools with an electric arc discharge for rock destruction contain low temperature plasma jets that outflow from one or a few nozzles in parallel or under an inclination angle to the axis of the borehole.

Table 3

Operating parameters of the plasmatron

\begin{tabular}{|l|c|}
\hline \multicolumn{1}{|c|}{ Parameter } & Value \\
\hline Power, $\mathrm{kW}$ & $120-140$ \\
\hline Air consumption, kg/s & $0.010-0.015$ \\
\hline Mass-averaged jet temperature, $\mathrm{K}$ & $2000-3000$ \\
\hline Mass-averaged velocity of the jet outflow, $\mathrm{m} / \mathrm{s}$ & $1000-1500$ \\
\hline Thermal efficiency & $0.7-0.85$ \\
\hline
\end{tabular}

Table 4

Operating parameters of the plasmatron

\begin{tabular}{|l|c|}
\hline \multicolumn{1}{|c|}{ Parameter } & Value \\
\hline Power, $\mathrm{kW}$ & $140-180$ \\
\hline Compressed air pressure, $\mathrm{MPa}$ & $0.4-0.5$ \\
\hline Air consumption, $\mathrm{m}^{3} / \mathrm{s}$ & $0.04-0.06$ \\
\hline Water pressure for cooling of electrodes, $\mathrm{MPa}$ & $0.8-1.0$ \\
\hline Water flow, $\mathrm{m}^{3} / \mathrm{s}$ & 0.65 \\
\hline
\end{tabular}

Reaming velocity of the borehole

\begin{tabular}{|l|c|}
\hline \multicolumn{1}{|c|}{ Parameter } & $\begin{array}{c}\text { Reaming } \\
\text { velocity, m/s }\end{array}$ \\
\hline $\begin{array}{l}\text { Borehole diameter after reaming up to } \\
200-250 \mathrm{~mm}\end{array}$ & $4.1-2.8$ \\
\hline $\begin{array}{l}\text { Borehole diameter after reaming up to } \\
300-350 \mathrm{~mm}\end{array}$ & $1.1-2.5$ \\
\hline $\begin{array}{l}\text { Borehole diameter after reaming up to } \\
450-500 \mathrm{~mm}\end{array}$ & $0.45-0.4$ \\
\hline
\end{tabular}

Table 6

Experimental investigation results

\begin{tabular}{|l|c|c|c|}
\hline \multirow{2}{*}{ Parameter } & \multicolumn{3}{|c|}{ Qalue } \\
\cline { 2 - 4 } & Quartzites & $\begin{array}{c}\text { Magnetite- } \\
\text { amphiboles }\end{array}$ & $\begin{array}{c}\text { Magnetite- } \\
\text { amphibole- } \\
\text { silicates }\end{array}$ \\
\hline $\begin{array}{l}\text { Plasmatron } \\
\text { power, kW }\end{array}$ & $170-175$ & $150-160$ & 150 \\
\hline $\begin{array}{l}\text { Initial borehole } \\
\text { diameter, mm }\end{array}$ & \multicolumn{2}{|c|}{105} \\
\hline $\begin{array}{l}\text { Borehole } \\
\text { diameter after } \\
\text { reaming, mm }\end{array}$ & $450-500$ & $270-320$ & $230-250$ \\
\hline $\begin{array}{l}\text { Velocity of the } \\
\text { plasmatron } \\
\text { nozzle in a } \\
\text { borehole, } \mathrm{m} / \mathrm{hr}\end{array}$ & 1.0 & 1.0 & 0.7 \\
\hline $\begin{array}{l}\text { Initial tempera- } \\
\text { ture of the heat } \\
\text { transfer medium, } \\
{ }^{\circ} \mathrm{C}\end{array}$ & no data & no data & $950-1000$ \\
\hline $\begin{array}{l}\text { Initial specific } \\
\text { heat flux from } \\
\text { the heat transfer } \\
\text { medium to the } \\
\text { rock surface, } \\
\text { W/m }{ }^{2}\end{array}$ & no data & no data & $(8.4-9.5) \cdot 10^{5}$ \\
\hline
\end{tabular}

Thus, the features of the known experimental research studies allow determining velocity of the heat transfer medium on the surface of the borehole and values of the heat transfer coefficient only for the conditions indicated in those publications.

Efficiency of thermal methods of rock destruction is defined by specific heat flux that is transfered from the heat transfer medium to the rock surface [10].

Specific heat flux can be augmented due to increase in the heat transfer medium temperature or heat transfer coefficient [11].

In case of rock destruction in the spallation mode, i.e. in case of thermal reaming of the boreholes, an increase in the heat transfer medium temperature is inexpedient, as it can lead to the rock melting [12].

In this case it is necessary to increase the heat transfer coefficient from the heat transfer medium to the rock 
surface due to the augmentation of the mass velocity of the heat transfer medium, i.e. increasing of the heat transfer medium rate and velocity [13].

Thus, application of the high-speed jets of the heat transfer medium is prospective in the processes of fragile rock destruction.

Objectives of the article. As the known results of experimental research studies dissatisfy the solution of tasks of the current work, fulfilment of our own experimental research of the interaction of high-speed heat transfer medium jets with the borehole surface is necessary.

Methods. Experimental research on the interaction of high-speed jets of the heat transfer medium with the borehole surface is executed as a lateral surface of the cross duct imitated the rock surface in a borehole.

From a compressor through the gate and regulative valves as well as prechamber, compressed air flows through the air duct directly to the nozzle.

The model that imitates the rock surface in a borehole is executed as a cross duct (Fig. 1).

For pressure determination in the air duct and prechamber the deformation standard manometers of 1227 model were used with a provisional scale of the MO type. The upper limit of measurement of the standard manometers is $1.6 \mathrm{MPa}$. The accuracy class of devices is 0.15 . The scale of device contains 400 provisional units; the scale interval of device is one provisional unit [14].

The essence of experimental investigation consisted of measurement of pressure on the lateral surface of the cross duct at the air jet impingement on the lateral surface.

For this purpose the drainage orifices in the cross duct are made that are connected by impulse tubes to the recording manometers.

The values of pressure on the lateral surface of the cross duct obtained during the experimental investigation are necessary for determination of the gas velocity along the lateral surface of the cross duct, which makes it possible to determine the heat transfer coefficient from the gas that imitates the heat transfer medium, to the lateral surface of the cross duct that imitates the rock surface in the borehole.

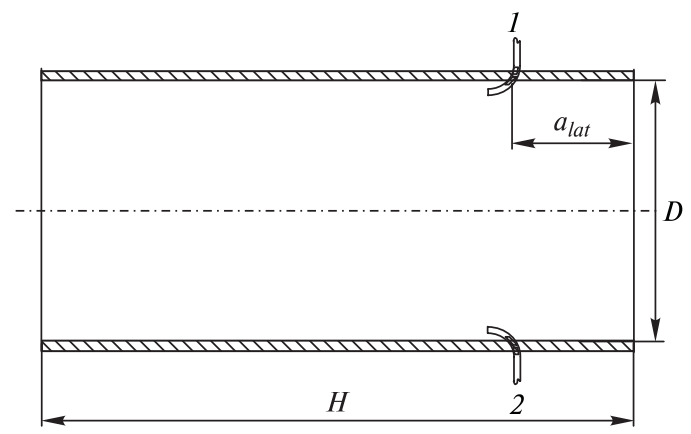

Fig. 1. The disposal of the drainage orifices in the cross duct:

1 and 2 -drainage orifices; $a_{\text {lat }}$ - distance from the drainage orifices to the end of the cross duct; $\mathrm{H}$ - cross duct length; $D$ - inner diameter of the cross duct
Drainage orifices $0.8 \mathrm{~mm}$ in diameter are executed in the normal line direction to the axis of the cross duct [15].

The copper tubes of total pressure were set in the drainage orifices. The edges of tubes are located on $0.3 \mathrm{~mm}$ above the inner surface of the duct and turned to the flow that impinges the duct, for measurement possibility of the total pressure of flow that enters the duct [16]. For the velocities of flow less than $M<2.3$ the error of total pressure measurement by a copper tube does not exceed $1 \%$ [17].

Rubber impulse tubes $2 \mathrm{~mm}$ in diameter from the drainage orifices of the cross duct are brought to the recording manometers. The maximum error of manometers measurement equals $0.5 \%$ of the maximal pressure value that is measured.

An experiment for interaction of the gas jet with the lateral surface of the cross duct involved values as follows:

- nozzle outlet diameter $\left(d_{0}\right)-0.012 ; 0.016 ; 0.020$; $0.022 ; 0.024 ; 0.027 \mathrm{~m}$;

- nozzle length $\left(L_{n o z}\right)-0.012 ; 0.016 ; 0.020 ; 0.022$; $0.024 ; 0.027 \mathrm{~m}$;

- inner diameter of the cross duct $(D)-0.04 ; 0.05$; $0.06 ; 0.08 \mathrm{~m}$;

- cross duct length $(H)-0.12 ; 0.15 ; 0.18 ; 0.24 \mathrm{~m}$, respectively;

- distance from the drainage orifices to the end of the cross duct $\left(a_{\text {lat }}\right)-0.024 \mathrm{~m}$;

- relative distance from the outlet orifice plain to the inlet cross duct plain $\left(\bar{h}=h / d_{0}\right)-0-0.30$;

- relative diameter of the cross duct $\bar{d}=d_{0} / D=0.20$;

$0.24 ; 0.25 ; 0.30 ; 0.32 ; 0.33 ; 0.44$;

- absolute air pressure before a nozzle in the prechamber $P_{n o z 0}=0.169-2.114 \mathrm{MPa}$;

- an angle between the axis of nozzle and axis of the cross duct $\varphi=0^{\circ}$;

- Mach number at the nozzle outlet $\left(M_{0}\right)-1.0$.

The geometrical parameters of the cross duct and the nozzle are adopted in accordance with geometrical similarity to the technological and processing parameters of plasmatron and diameter of boreholes before the beginning of the thermal reaming process.

An imitation of the plasma jet by means of air is absolutely acceptable, because an ionization level of the low temperature plasma used as the heat transfer medium in the processes of the rock thermal destruction does not exceed $1 \%$ [18].

Results. Fig. 2 shows dependence of absolute pressure at the lateral surface of the cross duct, i.e. absolute pressure on the rock surface, from relative pressure of air before a nozzle and relative diameter of the cross duct.

Comparison of pressure values of the gas jet on the inner surface of the cross duct allows making a conclusion that for other equal conditions pressure values on the inner surface of the cross duct increase with the augmentation of the pressure value at the nozzle inlet that testifies an adequacy of measurement results.

Fig. 2 shows that the increase in pressure at the nozzle inlet causes an augmentation of pressure, and, ac- 

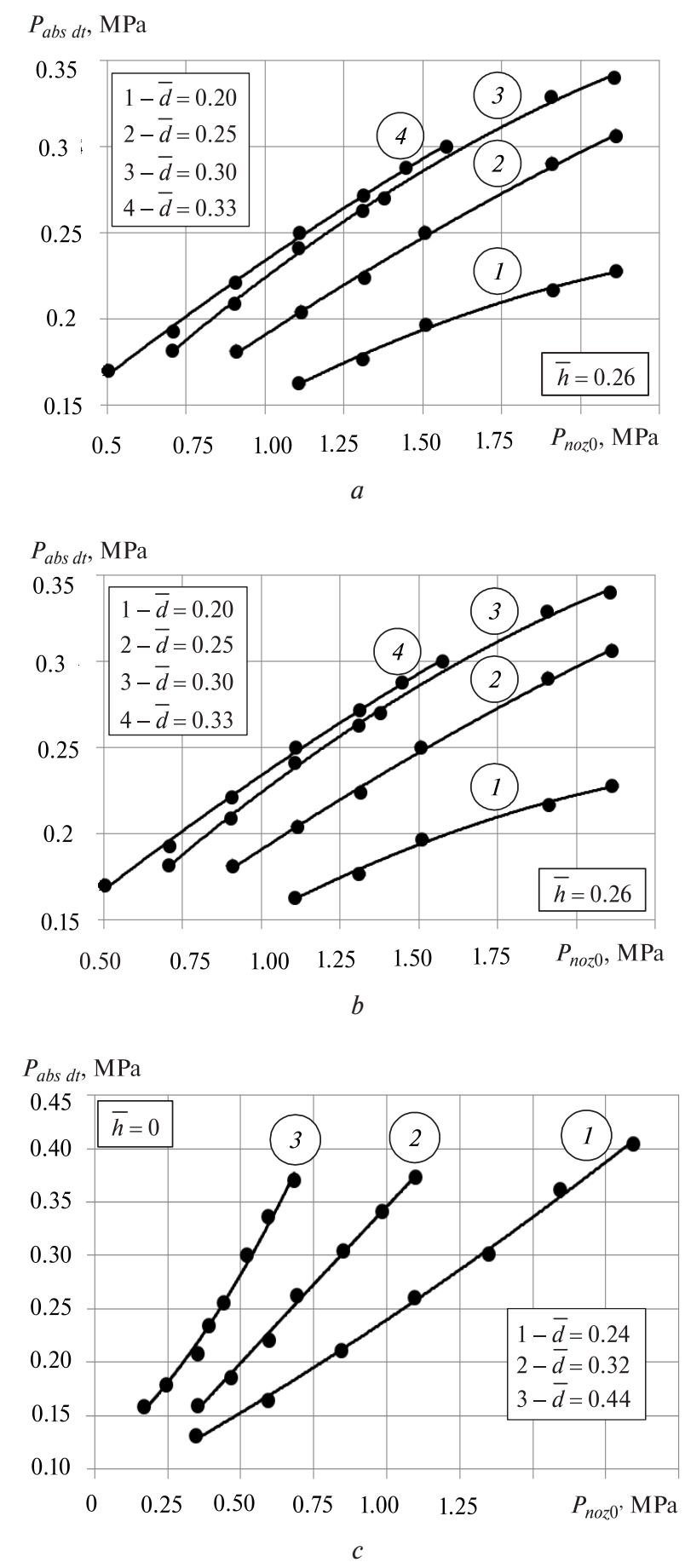

Fig. 2. Dependence of the absolute pressure values on the lateral surface of the cross duct $\left(P_{a b s} d t\right)$ on absolute pressure value of gas before a nozzle $\left(P_{\text {noz }}\right)$ : $a-\bar{h}=0 ; b-\bar{h}=0.26 ; c-\bar{h}=0.30$

cordingly, velocity of the heat transfer medium on the rock surface.

The reduction of relative diameter of the cross duct, i. e. the decrease in the nozzle inlet diameter or the increase in the inner diameter of the cross duct, leads to the augmentation of the heat transfer medium pressure, and, accordingly, augmentation of velocity of the heat transfer medium on the rock surface.
Thus, the results of the experimental investigation allow making a conclusion that the application of highspeed plasma jets and, actually, plasmatron as the thermal tool for rock destruction is a prospective direction of the scientific research.

Conclusions. The analysis of publications proves the availability of a small number of publications devoted to the experimental research on gas dynamics and plasma dynamics of the jets that are in application as a heat transfer medium in the thermal methods of rock destruction.

The expediency of the fulfilment of own experimental research studies of interaction of high-speed heat transfer medium jets with the inner surface of the borehole is substantiated.

The experimental research on interaction of highspeed heat transfer medium jets with the inner surface of the borehole is conducted as a lateral inner surface of the cross duct imitated the rock surface in a borehole.

The further prospects of this work are as follows: the determination of gas velocity along the lateral surface of the cross duct and the value of the heat transfer coefficient from the heat transfer medium to the lateral surface of the cross duct that imitates the rock surface in the borehole.

\section{References.}

1. Dmitriev, A.P., Goncharov, S.A. and Zilbershmidt, M. G., 2011. Contemporary problems of selective and energy saving rock destruction. Gornyy informatsionno-analiticheskiy byulleten, 1, pp. 169-184.

2. Bazargan, M., Gudmundsson, A., Meredith, P., Inskip, N. F., Soliman, M.Y., Fatideh, M. H., Rezaei, A. and Browning, J., 2015. Wellbore instability during plasma torch drilling in geothermal reservoirs. In: $49^{\text {th }} U S$ Rock Mechanics / Geomechanics Symposium, San Francisco, CA, June 28-July [online], ARMA, pp. 1-4. Available at: <https://www.researchgate.net/publication/275962154_Wellbore_instability_during_plasma_ torch_drilling_in_geothermal_reservoirs $>$ [Accessed $1 \overline{4}$ May 2017].

3. Kocis, I., Kristofic, T., Gajdos, M., Horvath, G. and Jankovic, S., 2015. Utilization of Electrical Plasma for Hard Rock Drilling and Casing Milling. In: SPE/IADC Drilling Conference and Exhibition, London, March 1719 [online], Society of Petroleum Engineers, pp. 1-14. Available at: <https://www.onepetro.org/conferencepaper/SPE-173016-MS $>$ [Accessed 6 August 2017].

4. Falshtynskyi, V., Dychkovskyi, V., Lozynskyi, V. and Saik, P., 2012. New method for justification of the technological parameters of coal gasification in the test setting. Geomechanical Processes During Underground Mining - Proceedings of the School of Underground Mining, pp. 201-208. DOI: 10.1201/b13157-35.

5. Dychkovskyi, R.O., Lozynskyi, V.H., Saik, P.B., Petlovanyi, M.V., Malanchuk, Ye.Z. and Malanchuk, Z. R., 2018. Modeling of the disjunctive geological fault influence on the exploitation wells stability during underground coal gasification. Archives of Civil and $\mathrm{Me}$ chanical Engineering, 18(3), pp.902-911. DOI: 10.1016/j. acme.2018.01.012. 
6. Sobolev, V. V. and Usherenko, S. M., 2006. Shockwave initiation of nuclear transmutation of chemical elements. Journal de Physique IV (Proceedings), 134, pp. 977-982. DOI: 10.1051/jp4:2006134149.

7. Filippov, A.I., Akhmetova, O. V. and Rodionov, A. S., 2012. Heat transfer of turbulent stream in a borehole. In: XV Minsk International Heat and Mass Transfer Forum, Minsk, September 10-13 [online], pp. 1-6. Available at: <www.itmo.by/ru/conferences/ mif_14/Section 1> [Accessed 7 July 2017].

8. Babayan, E. V. and Chernenko, A. V., 2016. Engineering calculations at the boring drilling. Moscow: Infra-Inzheneriya.

9. Gulin, V. V. and Ustimenko, T. A., 2014. Designing of generators of impulse jets on the basis of structural synthesis. Eastern-European Journal of Enterprise Technologies, 4(7), pp. 38-45.

10. Kant, M., Rossi, E., Höser, D. and von Rohr, P. R., 2017. Thermal Spallation Drilling, an Alternative Drilling Technology for Deep Heat Mining-Performance Analysis, Cost Assessment and Design Aspects. In: Proceedings, 42 ${ }^{\text {nd }}$ Workshop on Geothermal Reservoir Engineering, Stanford University, Stanford, CA, February 13-15 [online], pp. 1-10. Available at: <https://pangea.stanford.edu/ERE/db/GeoConf/papers / SGW/2017> [Accessed 7 August 2017].

11. Kant, M.A. and von Rohr, P. R., 2016. Minimal required boundary conditions for the thermal spallation process of granitic rocks. International Journal of Rock Mechanics and Mining Sciences, 84, pp. 177-186.

12. Galarraga, C., 2016. An unconventional fixed cutter cutting structure layout to drill through Hard, Abrasive Conglomerates in Deep Wells - A case study. In: Abu Dhabi International Petroleum Exhibition \& Conference, November 7-10, Society of Petroleum Engineers [online], pp. 1-10. Available at: <https://www.onepetro. org/conference-paper/SPE-182879-MS $>$ [Accessed 24 June 2017].

13. Brkic, D., Kant, M., Meier, T., Schuler, M. and Rohr, R., 2015. Influence of Process Parameters on Thermal Rock Fracturing under Ambient Conditions. In: Proceedings, World Geothermal Congress 2015, Melbourne, April 19-25 [pdf], pp. 1-6. Available at: <https://pangea.stanford.edu/ERE/db/ WGC/papers/WGC/2015/21039.pdf $>$ [Accessed 3 May 2017].

14. Pavese, F. and Min Beciet, G. M., 2013. Modern gas-based temperature and pressure measurements. New York: Springer.

15. Venkateshan, S.P., 2015. Mechanical Measurements. New York: Wiley.

16. Morris, A. and Langari, R., 2012. Measurement and Instrumentation: Theory and Application [pdf]. Amsterdam: Elsevier. Available at: <https://thetastash.files. wordpress.com/2016/01/measurement-instrumentation-theory-and-application-by-alan-s-morris-rezalangari.pdf $>$ [Accessed 17 September 2017].

17. Nawrocki, W., 2015. Measurement systems and sensors. New York: Artech House Publishers.

18. Nguyen-Kuok, S., 2014. Theory of low-temperature plasma physics. London: Springer.

\section{Вплив тиску струмини теплоносія на поверхню гірської породи у процесі термічного розширення свердловини \\ О. І. Волошин, І. Ю. Потапчук, О. В. Жевжик}

Інститут геотехнічної механіки імені М. С. Полякова НАН України, м. Дніпро, Україна, e-mail: OIVoloshyn1951@nas. gov.ua; IYPotapchuk@nas.gov.ua; OVZhevzhyk@nas.gov.ua

Мета. Експериментально встановити взаємодію високошвидкісних струмин теплоносія з поверхнею свердловини у процесі крихкого руйнування гірських порід з метою визначення швидкості руху теплоносія вздовж поверхні свердловини й коефіцієнта тепловіддачі від теплоносія до поверхні гірської породи.

Методика. Використані методи порівняльного аналізу, математичного й фізичного імітаційного моделювання, експериментальні дослідження.

Результати. Розроблена методика експериментального дослідження взаємодії високошвидкісних струмин теплоносія з поверхнею свердловини у вигляді наскрізного каналу, бокова поверхня якого імітувала поверхню гірської породи у свердловині. Виконане експериментальне дослідження, що полягало у вимірюванні тиску на бічну поверхню наскрізного каналу при натіканні на нього повітряної струмини. Виконана обробка дослідних даних у вигляді залежності абсолютного тиску на бічну поверхню наскрізного каналу, тобто на поверхню гірської породи, від відносного тиску повітря перед соплом і відносного діаметру наскрізного каналу. Виявлені залежності між значеннями тиску перед соплом і значеннями тиску на поверхні гірської породи; значеннями відносного діаметру наскрізного каналу, діаметру вихідного отвору сопла, внутрішнього діаметру наскрізного каналу й значеннями тиску повітря вздовж бічної поверхні каналу.

Наукова новизна. Полягає у проведенні фізичного імітаційного моделювання взаємодії високошвидкісних струмин теплоносія з поверхнею свердловини в певному діапазоні геометричних параметрів наскрізного каналу й сопла, що прийняті у відповідності до геометричної подоби технологічним і конструктивним параметрам плазмотрона й діаметра свердловин перед початком процесу термічного розширення.

Практична значимість. Обгрунтування доцільності використання високошвидкісних струмин плазми в якості термоінструмента у процесах крихкого руйнування гірських порід i, зокрема, у процесах термічного розширення свердловин.

Ключові слова: гірська порода, свердловина, крихке руйнування, термічне розширення, плазма

\section{Влияние давления струи теплоносителя на поверхность горной породы в процессе термического расширения скважины}

\section{А. И. Волошин, И. Ю. Потапчук, А. В. Жевжик}

Институт геотехнической механики имени М.С. Полякова НАН Украины, г. Днепр, Украина, e-mail: OIVoloshyn1951@ nas.gov.ua; IYPotapchuk@nas.gov.ua; OVZhevzhyk@nas.gov. ua

ISSN 2071-2227, Naukovyi Visnyk NHU, 2018, № 2 
Цель. Экспериментально установить взаимодействие высокоскоростных струй теплоносителя с поверхностью скважины в процессе хрупкого разрушения горных пород с целью определения скорости движения теплоносителя вдоль поверхности скважины и коэффициента теплоотдачи от теплоносителя к поверхности горной породы.

Методика. Использованы методы сравнительного анализа, математического и физического имитационного моделирования, экспериментальные исследования.

Результаты. Разработана методика экспериментального исследования взаимодействия высокоскоростных струй теплоносителя с поверхностью скважины в виде сквозного канала, боковая поверхность которого имитировала поверхность горной породы в скважине. Выполнено экспериментальное исследование, которое заключалось в измерении давления на боковую поверхность сквозного канала при натекании на него воздушной струи. Выполнена обработка экспериментальных данных в виде зависимости абсолютного давления на боковую поверхность сквозного канала, т.е. на поверхность горной породы, от относительного диаметра сквозного канала. Определены зависимости между значениями давления перед соплом и значениями давления на поверхности горной породы; значениями относительного диаметра сквозного канала, диаметра выходного отверстия сопла, внутреннего диаметра сквозного канала и значениями давления воздуха вдоль боковой поверхности канала.

Научная новизна. Заключается в проведении физического имитационного моделирования взаимодействия высокоскоростных струй теплоносителя с поверхностью скважины в определенном диапазоне геометрических параметров сквозного канала и сопла, которые приняты в соответствии с геометрическим подобием технологическим и конструктивным параметрам плазмотрона и диаметра скважины перед началом процесса термического расширения.

Практическая значимость. Обоснование целесообразности использования высокоскоростных струй плазмы в качестве термоинструмента в процессах хрупкого разрушения горных пород и, в частности, в процессах термического расширения скважин.

Ключевые слова: горная порода, скважина, хрупкое разрушение, термическое расширение, плазма

Рекомендовано до публікації докт. техн. наук В. П. Надутим. Дата надходження рукопису 23.01.17. 